\title{
Revascularization and cardioprotective drug treatment in myocardial infarction patients: how do they impact on patients' survival when delivered as usual care
} Alain Vanasse*1,2, Josiane Courteau ${ }^{2}$ and Théophile Niyonsenga ${ }^{3}$

\begin{abstract}
Address: ${ }^{1}$ Family Medicine Department, Faculty of Medicine, Université de Sherbrooke, 3001, 12th Avenue North, Sherbrooke (QC), J1H 5N4, Canada, 2 PRIMUS Group, Clinical Research Center, Sherbrooke University Hospital, Sherbrooke (QC), Canada and ${ }^{3}$ Stempel School of Public Health, Epidemiology \& Biostatistics, Florida International University, Florida, USA
\end{abstract}

Email: Alain Vanasse* - alain.vanasse@usherbrooke.ca; Josiane Courteau - josiane.courteau@chus.qc.ca; Théophile Niyonsenga - niyonsen@fiu.edu

* Corresponding author

\section{Published: 04 May 2006}

BMC Cardiovascular Disorders 2006, 6:21 doi:10.1|86/|47|-226|-6-21
Received: 16 January 2006

Accepted: 04 May 2006

This article is available from: http://www.biomedcentral.com/I47I-226I/6/2I

(c) 2006 Vanasse et al; licensee BioMed Central Ltd.

This is an Open Access article distributed under the terms of the Creative Commons Attribution License (http://creativecommons.org/licenses/by/2.0), which permits unrestricted use, distribution, and reproduction in any medium, provided the original work is properly cited.

\begin{abstract}
Background: Randomized clinical trials showed the benefit of pharmacological and revascularization treatments in secondary prevention of myocardial infarction (MI), in selected population with highly controlled interventions. The objective of this study is to measure these treatments' impact on the cardiovascular (CV) mortality rate among patients receiving usual care in the province of Quebec.

Methods: The study population consisted of a "naturalistic" cohort of all patients $\geq 65$ years old living in the Quebec province, who survived a MI (ICD-9: 4I0) in 1998. The studied dependant variable was time to death from a CV disease. Independent variables were revascularization procedure and cardioprotective drugs. Death from a non CV disease was also studied for comparison. Revascularization procedure was defined as percutaneous transluminal coronary angioplasty (PTCA) or coronary artery bypass graft (CABG). The exposure to cardioprotective drugs was defined as the number of cardioprotective drug classes (Acetylsalicylic Acid (ASA), Beta-Blockers, Angiotensin-Converting Enzyme (ACE) Inhibitors, Statins) claimed within the index period (first 30 days after the index hospitalization). Age, gender and a comorbidity index were used as covariates. Kaplan-Meier survival curves, Cox proportional hazard models, logistic regressions and regression trees were used.

Results: The study population totaled 5596 patients ( 3206 men; 2390 women). We observed I 128 deaths (20\%) within two years following index hospitalization, of them 603 from CV disease. The CV survival rate at two years is much greater for patients with revascularization, regardless of pharmacological treatments. For patients without revascularization, the $\mathrm{CV}$ survival rate increases with the number of cardioprotective drug classes claimed. Finally, Cox proportional hazard models, regression tree and logistic regression analyses all revealed that the absence of revascularization and, to a lower extent, absence of cardioprotective drugs were major predictors for $\mathrm{CV}$ death, even after adjusting for age, gender and comorbidity.

Conclusion: Considering usual care management of $\mathrm{MI}$ in the province of Quebec in 1998, CV survival is positively correlated to the presence of a revascularization procedure and to the intensity of cardioprotective pharmacological treatment. These results are coherent with data from randomized control trials.
\end{abstract}




\section{Background}

Cardiovascular events represent a major health burden for Canada and other modern societies and myocardial infarction (MI) accounts for a large percentage of them. MI is a very lethal disease with near $30 \%$ of deaths, among which near half occurs before arriving to hospital [1]. The prognosis of this clinical event depends on the patient's acknowledgement of his clinical symptoms and the decision to seek for medical care; on the delay between the first symptoms and the arrival to hospital (onset-to-door); on the emergency care team rapidity of response, and on the swiftness and suitability of the treatment received during hospitalization [2,3], but also after discharge. MI secondary prevention includes all clinical measures taken after the event's occurrence to reduce mortality and/or morbidity of the disease. Cardiovascular secondary prevention includes appropriate revascularization procedures and long term use of known cardioprotective drugs - Acetylsalicylic Acid (ASA), Beta-Blockers, AngiotensinConverting Enzyme (ACE) Inhibitors, Statins - as well as risk factors reduction with long term lifestyle and/or drug management. Practice guidelines regarding MI management have been widely published in the last decade [4-7].

These clinical guidelines are based on evidence that early revascularization reduces mortality and morbidity [8-12]. However, some clinical trials showed only marginal benefits of revascularization $[13,14]$. Each of the four pharmacological classes included in the guidelines has also individually demonstrated great benefits to prevent mortality and morbidity in secondary prevention [15-36]. Some combinations of these drug classes have also showed reduced mortality [37-39]. In 2004, Mukherjee et al [40] have demonstrated an improvement in 6-month mortality after an acute coronary syndrome according to a composite appropriateness score defined by a combination of these four drug classes. To our knowledge, little is known about the impact of the combination of these four classes of drugs in addition to revascularization procedure in the general population.

The main objective of this study is to measure in the context of usual care, the impact of surgical (PTCA and $\mathrm{CABG}$ ) and pharmacological treatments (revascularization and/or the number of type of cardioprotective drugs claimed) on the cardiovascular (CV) survival rate of patients with MI in 1998 in Quebec.

\section{Methods \\ Design}

We conducted a population-based cohort study using secondary data analysis from the Quebec's hospital discharge register (MED-ECHO). This register provides administrative data on patients hospitalized in the province of Quebec. Studies confirming the validity of the administrative hospital discharge data concerning MI have previously been published $[41,42]$.

\section{Studied population}

The study population included all patients 65 years and older living in the province of Quebec, who have been hospitalized in Quebec for a MI between January $1^{\text {st }}$ and December $31^{\text {st }} 1998$. We will refer as the "index period" the period defined by the first hospitalization in addition to a 30-day period after discharge from the index hospitalization. We included patients who were hospitalized for acute myocardial infarction (code 410 of the International Disease Classification, $9^{\text {th }}$ revision (IDC-9)) as the main diagnosis. Patients with a MI in the year preceding the index hospitalization were excluded in order to include only new or stable MI cases. Patients from northern and low populated regions (Northern Quebec, Nunavik and James Bay Cree Lands) were excluded as well because of major cultural, social and health care services differences. In order to measure the pharmacological treatments claimed after the MI event, only patients who survived the index period were included in the analyses. A 2-year follow-up period was retained to collect the date and cause of death.

\section{Data sources}

All patients' data were obtained from the Quebec's hospital discharge register (MED-ECHO) and the provincial demographic database. For claimed drugs, we used the provincial pharmacological register administered by the Régie de l'assurance maladie du Québec (RAMQ), which covers almost all people aged 65 years or more as well as welfare recipients and people not covered by private drug insurance.

\section{Studied variables}

The main outcome of interest was time to death from CV cause (ICD-9: 410-414, 426-429). Exposure to revascularization was defined as 1 if there was mention of a PTCA or a CABG, as coded in the Quebec's hospital discharge register (Canadian Classification of diagnostic, therapeutic and surgical procedures (CCP) beginning with 480 to 483), for the index period and 0 otherwise. Exposure to medication was defined as the number of cardioprotective drug classes that was claimed within the index period. The following drug classes were considered: ASA, $\beta$-blockers, ACE inhibitors, and Statins.

Covariates included gender, age, and a comorbidity index. This index is an adaptation of the D'Hoore index, which is itself an adaptation of the Charlson comorbidity index [43]. The D'Hoore index is a weighted score of comorbid conditions, these conditions being defined by the secondary diagnoses available in the MED-ECHO database in the year preceding the index hospitalization. We adapted this 
index simply by substracting the quantity 1 to the D'Hoore index, corresponding to the weight associated to the MI comorbid condition.

\section{Statistical analyses}

The chi-square test was used for comparison between proportions, whereas for comparison between means, the ttest or ANOVA was used depending on the number of groups. Survival analyses were done using Kaplan-Meier estimates for unadjusted survival curves (the homogeneity between the curves is tested using the Wilcoxon statistics) and Cox proportional hazard model to obtain death rates adjusted for all the covariates. Logistic regression $[44]$ and regression tree $[45,46]$ analyses were also performed to predict the CV death rate after two years. In regression tree methodology, information on a data set is summarized by dividing the population into a number of subgroups, as homogeneous as possible but distinct with respect to the parameters to predict. The subgroups are identified by a tree-structured figure of binary questions on the predictors. The resulting classification is the most informative one with respect to the parameter in question. Tree-growing techniques [47-49] are particularly suited to handle a large number of variables including some with missing values and to investigate the interactions between them. For all approaches, the potential patient-level predictors were age, gender, the comorbidity index, the presence/absence of a revascularization and the number of cardioprotective drugs claimed within the index period. The trees were pruned at a significance level of 0.001. For all other tests, the significance level used was 0.05 . Statistical analyses were done using SAS Release 9.1 and the RTREE program $[45,46]$.

\section{Ethical considerations}

This project was approved by the Sherbrooke University Hospital Ethics Board and the Commission d'accès à l'information du Québec.

\section{Results}

A total of 7332 patients 65 years or older have been hospitalized for a MI in Quebec between January 1st, 1998 and December 31st, 1998. Of those, 172 patients were excluded because they had a MI in the prior year, and 11 because they lived in the Quebec Northern regions. From the remaining 7149 patients, $1553(21,7 \%)$ died at the index period and were removed from the analyses. Therefore, the study population includes 5596 patients, men accounting for $57 \%(n=3206)$ of it. Table 1 presents the cohort's characteristics in regard to gender, age and comorbidity index, according to whether they survived the index period or not. Men, younger patients and patients with a lower comorbidity index are more represented in the cohort who survived the index period. Table 2 presents the patients' characteristics according to the revascularization procedure and to the number of cardioprotective drug classes claimed during the index period. This table reveals that men and younger patients, as well as patients with a lower comorbidity index have more chances of receiving a revascularization. On the other hand, age and comorbidity index, but not gender, are statistically associated with the number of cardioprotective drug classes claimed at the index period.

Of the 5596 cohort patients who survived the index period, $603(10.8 \%)$ died from CV disease and 525 $(9.4 \%)$ from another cause. Table 3 presents a cross tabu-

Table I: Description of the population with MI in Quebec in 1998

\begin{tabular}{|c|c|c|c|c|}
\hline & Total population & Died at index period & Survived index period & $p$-value \\
\hline TOTAL & 7149 & 1553 (2I.7\%) & $5596(78.3 \%)$ & \\
\hline \multicolumn{5}{|l|}{ Gender } \\
\hline Men & 3982 (55.7\%) & $776(50.0 \%)$ & 3206 (57.3\%) & $<.0001$ \\
\hline Women & 3167 (44.3\%) & 777 (50.0\%) & $2390(42.7 \%)$ & \\
\hline \multicolumn{5}{|l|}{ Age } \\
\hline Mean \pm SD & $76.1 \pm 7.3$ & $78.9 \pm 7.5$ & $75.3 \pm 7.0$ & $<.0001$ \\
\hline $65-74$ years & $3298(46.1 \%)$ & 487 (31.4\%) & $2811(50.2 \%)$ & $<.0001$ \\
\hline $75-84$ years & $2823(39.5 \%)$ & $674(43.4 \%)$ & 2149 (38.4\%) & \\
\hline$\geq 85$ years & $1028(14.4 \%)$ & $392(25.2 \%)$ & $636(11.4 \%)$ & \\
\hline \multicolumn{5}{|l|}{ Comorbidity index } \\
\hline Mean \pm SD (median) & $1.8 \pm 1.9(1)$ & $2.4 \pm 2.1(2)$ & $1.6 \pm 1.8(1)$ & $<.0001$ \\
\hline 0 & $2345(32.8 \%)$ & $333(21.4 \%)$ & $2012(36.0 \%)$ & $<.0001$ \\
\hline $1-2$ & $2624(36.7 \%)$ & $547(35.2 \%)$ & 2077 (37.1\%) & \\
\hline $3-4$ & $1538(21.5 \%)$ & $427(27.5 \%)$ & $1111(19.9 \%)$ & \\
\hline $5-6$ & 499 (7.0\%) & $181(11.7 \%)$ & $318(5.7 \%)$ & \\
\hline$\geq 7$ & $143(2.0 \%)$ & $65(4.2 \%)$ & 78 (I.4\%) & \\
\hline
\end{tabular}


Table 2: Characteristics of MI patients according to exposure to revascularization and medication $(n=5596)$

\begin{tabular}{|c|c|c|c|c|c|}
\hline & Total & Men & Women & Age (years) Mean $( \pm S D)$ & Comorbidity index Mean ( $\pm S D$ ) \\
\hline \multicolumn{6}{|c|}{ Revascularization } \\
\hline No & 4473 & $2505(56.0 \%)^{\mathrm{a}}$ & 1968 (44.0\%) & $76.2( \pm 7.2)^{\mathrm{b}}$ & $\mathrm{I} .7( \pm \mathrm{I} .8)^{\mathrm{b}}$ \\
\hline Yes & 1123 & 701 (62.4\%) & $422(37.6 \%)$ & $72.0( \pm 5.2)$ & $1.3( \pm 1.5)$ \\
\hline PTCA & 767 & $470(61.3 \%)$ & $297(38.7 \%)$ & $72.1( \pm 5.4)$ & $1.1( \pm 1.4)$ \\
\hline CABG & 356 & $231(64.9 \%)$ & $125(35.1 \%)$ & $71.6( \pm 4.7)$ & $1.5( \pm 1.6)$ \\
\hline \multicolumn{6}{|c|}{ Number of drug classes } \\
\hline 0 & 757 & $413(54.6 \%)^{c}$ & $344(45.4 \%)$ & $76.3( \pm 8.0)^{\mathrm{b}}$ & $2.0( \pm 1.9)^{b}$ \\
\hline 1 & 1166 & $682(58.5 \%)$ & $484(41.5 \%)$ & $76.5( \pm 7.1)$ & $1.8( \pm 1.8)$ \\
\hline 2 & 2046 & $1190(58.2 \%)$ & $856(41.8 \%)$ & $75.4( \pm 6.9)$ & $1.6( \pm 1.8)$ \\
\hline 3 & 1315 & $74 \mathrm{I}(56.3 \%)$ & $574(43.7 \%)$ & $74.0( \pm 6.4)$ & $1.4( \pm 1.6)$ \\
\hline 4 & 312 & $180(57.7 \%)$ & $132(42.3 \%)$ & $73.4( \pm 5.6)$ & $1.5( \pm 1.6)$ \\
\hline
\end{tabular}

a The difference between rates of men according to revascularization is statistically significant $(p=0.0003)$

b The differences between means (age and Comorbidity index) according to revascularization and number of drug classes are all statistically significant $(p<.000 \mathrm{I})$

$c$ The difference between rates of men according to number of drug classes is not statistically significant $(p=0.3889)$

lation of the covariates including care (revascularization and cardioprotective drugs) and the 2-year death rates. Here again, younger patients and patients with low comorbidity index have lower $\mathrm{CV}$ death rates and non $\mathrm{CV}$ death rates at 2 years. More than 1 out of 8 patients $(12.7 \%)$ on which no revascularization was performed at the index period died from a CV cause after 2 years, and $10.7 \%$ from another cause. However the differences in death rates between PTCA and CABG were not statistically significant. Similarly, one out of six (15.5\%) patients who did not claim any cardioprotective drugs within the first 30 days after the index hospitalization died from CV dis-

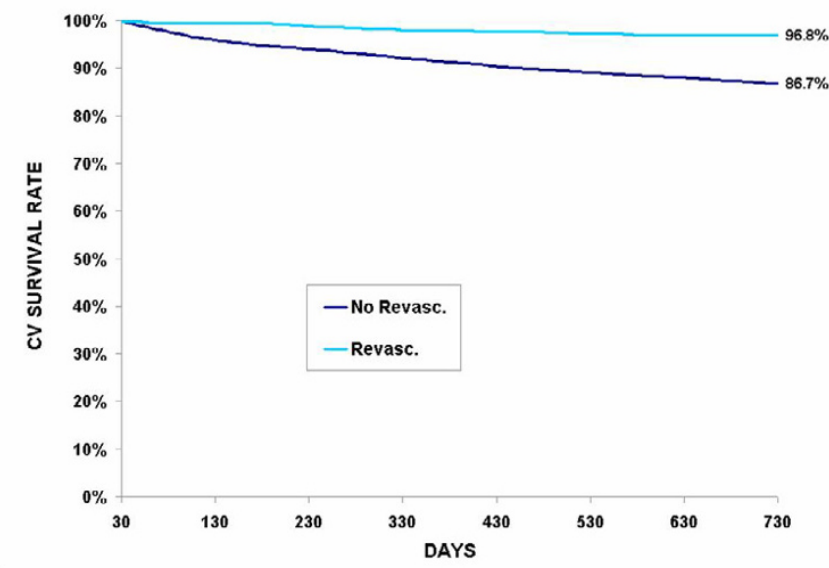

Figure I

Unadjusted Kaplan-Meier cardiovascular (CV) survival curves according to presence/absence of revascularization during index period among survivors at 30 days $(\mathbf{n}=\mathbf{5 5 9 6}) * *$ The curves are statistically different $(\mathrm{p}<.000 \mathrm{I})$. ease within 2 years. Here again, patients receiving the most intensive treatment (all four cardioprotective drug classes combined) benefited the most. The same trend is also observed in non $\mathrm{CV}$ death rates but to a lesser extent. The cardiovascular survival is clearly demonstrated in Figure 1 to Figure 3 where unadjusted Kaplan-Meier estimates show basically the same relation between the revascularization, the number of cardioprotective drug classes claimed at the index period and the $\mathrm{CV}$ survival rate. These curves also demonstrate that $\mathrm{CV}$ survival rate is greater for patients with revascularization, regardless of the number of cardioprotective drug classes claimed at the

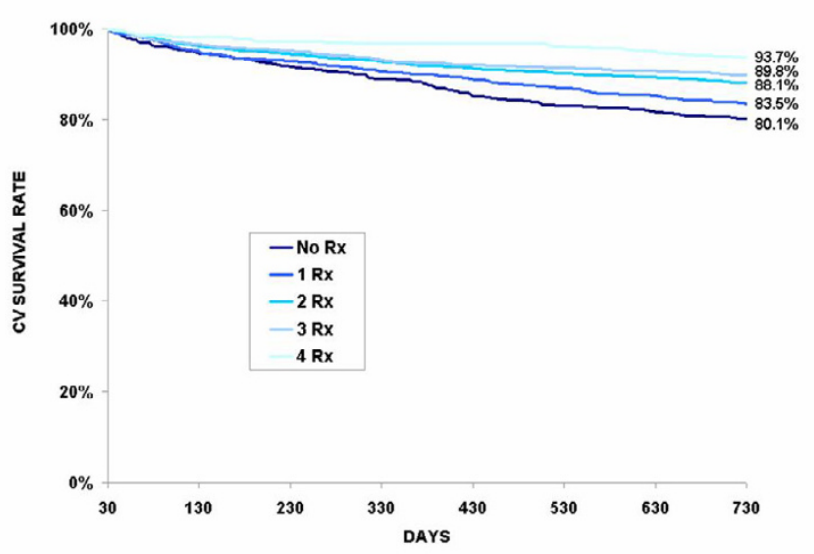

Figure 2

Unadjusted Kaplan-Meier cardiovascular (CV) survival curves according to the number of cardiovascular drug classes claimed during index period among survivors at 30 days who did not receive a revascularization $(n=4473)$. * The curves are statistically different $(p$ $<.0001)$ 
Table 3: Two-year death rates according to patients' characteristics and exposure to revascularization and medication $(n=5596)$

\begin{tabular}{|c|c|c|c|}
\hline & Total & 2-year CV death & 2-year non-CV death \\
\hline Total & 5596 & $603(10.8 \%)$ & 525 (9.4\%) \\
\hline Mean Age $\pm S D$ & 5596 & $79.3 \pm 7.3$ & $77.0 \pm 7.4$ \\
\hline \multicolumn{4}{|l|}{ Gender } \\
\hline Women & 2390 & $291(12.2 \%)^{\mathrm{a}}$ & $215(9.0 \%)^{d}$ \\
\hline Men & 3206 & $312(9.7 \%)$ & $310(9.7 \%)$ \\
\hline \multicolumn{4}{|l|}{ Comorbidity index } \\
\hline Mean \pm SD (median) & 5596 & $2.6 \pm 1.9(2)$ & $2.6 \pm 2.1(2)$ \\
\hline 0 & 2012 & $83(4.1 \%)^{\mathrm{b}}$ & $89(4.4 \%)^{\mathrm{b}}$ \\
\hline $\mathrm{I}-2$ & 2077 & 227 (10.9\%) & $188(9.0 \%)$ \\
\hline $3-4$ & 1111 & 197 (I7.7\%) & $152(13.7 \%)$ \\
\hline $5-6$ & 318 & $77(24.2 \%)$ & $72(22.6 \%)$ \\
\hline$\geq 7$ & 78 & $19(24.4 \%)$ & $24(30.8 \%)$ \\
\hline \multicolumn{4}{|l|}{ Revascularization } \\
\hline No & 4473 & $567(12.7 \%)^{c}$ & $478(10.7 \%)^{c}$ \\
\hline Yes & 1123 & $36(3.2 \%)$ & $47(4.2 \%)$ \\
\hline PTCA & 767 & $24(3.1 \%)^{d}$ & $33(4.3 \%)^{d}$ \\
\hline CABG & 356 & $12(3.4 \%)$ & 14 (3.9\%) \\
\hline \multicolumn{4}{|l|}{ Number of drug classes } \\
\hline 0 & 757 & $117(15.5 \%)^{e}$ & $113(14.9 \%)^{e}$ \\
\hline I & 1166 & $162(13.9 \%)$ & $136(11.7 \%)$ \\
\hline 2 & 2046 & $207(10.1 \%)$ & $178(8.7 \%)$ \\
\hline 3 & 1315 & $103(7.8 \%)$ & 78 (5.9\%) \\
\hline 4 & 312 & 14 (4.5\%) & $20(6.4 \%)$ \\
\hline
\end{tabular}

a The difference in $\mathrm{CV}$ death and in non- $\mathrm{CV}$ death rates between genders is statistically significant $(p=.0003)$

$\mathrm{b}$ The difference in $\mathrm{CV}$ death and in non-CV death rates between Comorbidity index groups is statistically significant $(p<0.0001)$

c The difference in $C V$ death and in non-CV death rates according to presence/absence of revascularization is statistically significant $(\mathrm{P}<$ $0.0001)$

d The difference in $C V$ death and in non-CV death rates according to PTCA or CABG is not statistically significant $(p>0.05)$

e The difference in CV death and in non-CV death rates according to number of drugs classes claimed is statistically significant $(p<0.000 \mathrm{I})$

index period. For patients without revascularization, CV survival rate increases with the number of cardioprotective drugs claimed (Figure 2).

Cox proportional hazard models (Table 4) show that adjusted CV death rate increases with age and also with comorbidity index. The hazard ratio (HR) is much lower for patients with revascularization as well as proportionally with the number of classes of cardioprotective drugs claimed.

Regression tree and logistic regression analyses (Figure 4) provide complementary information on variables related to a greater chance of survival 2 years after a MI. The CV death rates vary from $0.1 \%$ for younger individuals who

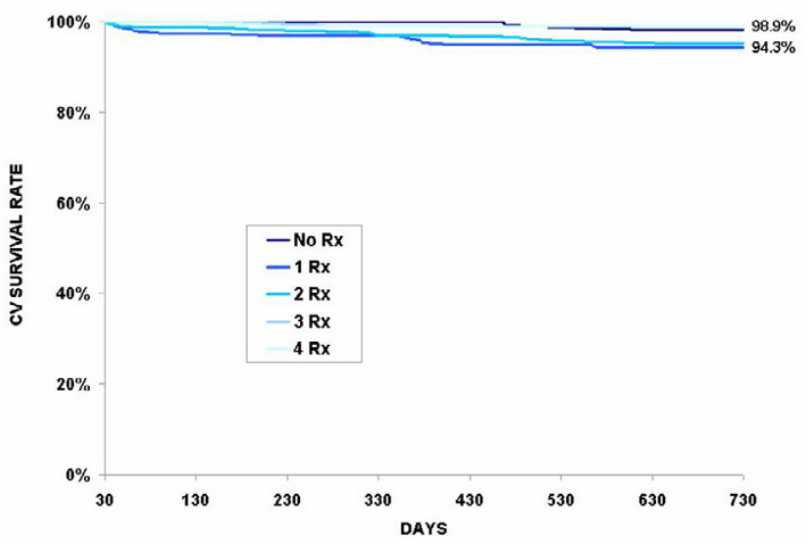

Figure 3

Unadjusted Kaplan-Meier cardiovascular (CV) survival curves according to the number of cardiovascular drug classes claimed during index period among survivors at $\mathbf{3 0}$ days who received a revascularization $(\mathbf{n}=I \mid 23)$. * The curves are statistically different $(\mathrm{P}=$ 0.006)

had a revascularization with no comorbid conditions to $39.1 \%$ for very old patients with comorbidities. For older patients without comorbidities, the use of cardioprotective drugs lowers the 2-year death rates from $22.2 \%$ to $8.6 \%$. For younger patients with comorbidities, revascularization decreases the death rates from $9.4 \%$ to $3.6 \%$.

\section{Discussion}

The major findings of this population-based cohort study are that CV survival is strongly correlated with revascularization and, at a lesser extent, to the number of classes of cardioprotective drugs claimed. Moreover, the benefit seems to be additive. It is not surprising that populations with and without revascularization differ in age, sex and comorbidity index. However, even after controlling for these factors (Cox proportional hazard model), CV survival remains strongly correlated with revascularization.

Differences between the survival curves may possibly reflect clinical differences unconsidered in the comorbidity index, like non-Q wave myocardial infarction $[50,51]$. It may also reflect the socio-economical status related to the patient or broader variables like the care setting $[52,53]$, or geographical factors like rural - urban differences [54-56]. This study also demonstrates that survival rate increases with the number of cardioprotective drugs claimed. Similar results were found by Murkherjee et al [40] using an appropriateness algorithm for the use of each secondary pharmacological prevention strategies. In their paper, the score was dependent on the number of 
Table 4: Time to death from all cause and time to cardiovascular (CV) death: Cox proportional hazard models $(n=5596)$

\begin{tabular}{lrr}
\hline & \multicolumn{2}{c}{ Time to CV death } \\
\hline & Crude HR $(95 \%$ Cl) & Adjusted HR* $(95 \%$ Cl) \\
\hline Age & $1.087(1.076 ; 1.099)$ & $1.069(1.057 ; 1.082)$ \\
Male gender & $0.785(0.669 ; 0.921)$ & $1.010(0.857 ; 1.190)$ \\
Comorbidity index & $1.315(1.271 ; 1.362)$ & $1.266(1.222 ; 1.312)$ \\
Revascularization (PTCA or CABG) & $0.232(0.165 ; 0.324)$ & $0.368(0.261 ; 0.518)$ \\
Number of classes of medication & $0.749(0.696 ; 0.806)$ & $0.853(0.790 ; 0.920)$ \\
\hline
\end{tabular}

* Adjusted for all covariables

medication classes taken among those indicated for the patient. They showed a clear association between an increased score, corresponding to more treatment, and decreased death rates after 6 months.

One can also observe that non cardiovascular survival is increased with revascularization and cardioprotective drugs. However, the extent of this increase is less important than the one observed in cardiovascular survival. We can put forward the hypothesis that the use of revascularization and cardioprotective drugs can reflect a better health care management in general, leading to an increase in non cardiovascular survival as well as in cardiovascular survival.

The major strength of this study is its "naturalistic" population-based cohort. The use of these cohorts can produce results reflecting more closely the real impact of treatment in usual care. Although we acknowledge that validity may possibly be threatened by multiple unrecognized biases, the adjustment for age, sex and comorbidity index, as well as the use of regression tree analysis provide us with more comprehensive knowledge of the relationship between usual care management and survival after a MI.

One of the logistic regression approach disadvantages is that some variables may exert their effect on the whole population while others may be relevant only in specific subgroups (global and local effects). Indeed, for the logistic regression approach, variables enter the equation as main effects. Interactions can be added if they make sense or if based on a priori specified hypothesis. This drawback was overcome by using the regression tree approach [47$49]$ which creates specific subpopulations according to death rates. These regression tree analyses bring forward some considerations on good care management in respect to subpopulations. It also shows that there is not one better treatment for all and that both revascularization and cardioprotective drugs bring significant benefit alone or in combination.
The major limitation of this study is inherent to the use of administrative databases, for example, it was not possible to take in consideration indication and contraindication of revascularization procedures and cardioprotective drugs according to specific clinical condition (STEMI/ NSTEMI).

\section{Conclusion}

This study reveals that, when considering usual care for MI, survival is positively correlated with revascularization and the number of cardioprotective drug classes claimed. In this study, important predictors of cardiovascular death after 2 years were the absence of revascularization, older age and higher comorbidity index.

\section{Competing interests}

This project has benefited from an unrestricted grant by Merck Frosst Canada Ltd. This grant was part of a peer reviewed grant obtained from GEOIDE Networks of Centers of Excellence of Canada. None of the authors received salaries, consultation fees or any reimbursement from this company, nor held any shares in this organization.

\section{Authors' contributions}

$\mathrm{AV}, \mathrm{TN}$, and JC conceived the study, JC performed the analyses. All authors participated to the writing of the manuscript. All authors read and approved the final version of the manuscript.

\section{Acknowledgements}

This project was subsidized by the GEOIDE Network of Centers of Excellence and Merck Frosst Canada Ltd. The principal investigator was supported by the Department of Family Medicine, Université de Sherbrooke; the Clinical Research Center, Sherbrooke University Hospital; and the Fonds de Recherche en Santé du Québec.

\section{References}

I. Fondation des maladies du Coeur: Le Fardeau croissant des maladies cardiovasculaires et des accidents vasculaires cérébraux au Canada Ottawa, Canada; 2003.

2. Cannon CP, Gibson CM, Lambrew CT, Shoultz DA, Levy D, French WJ, Gore JM, Weaver WD, Rogers WJ, Tiefenbrunn AJ: Relationship of symptom-onset-to-balloon time and door-to-balloon 


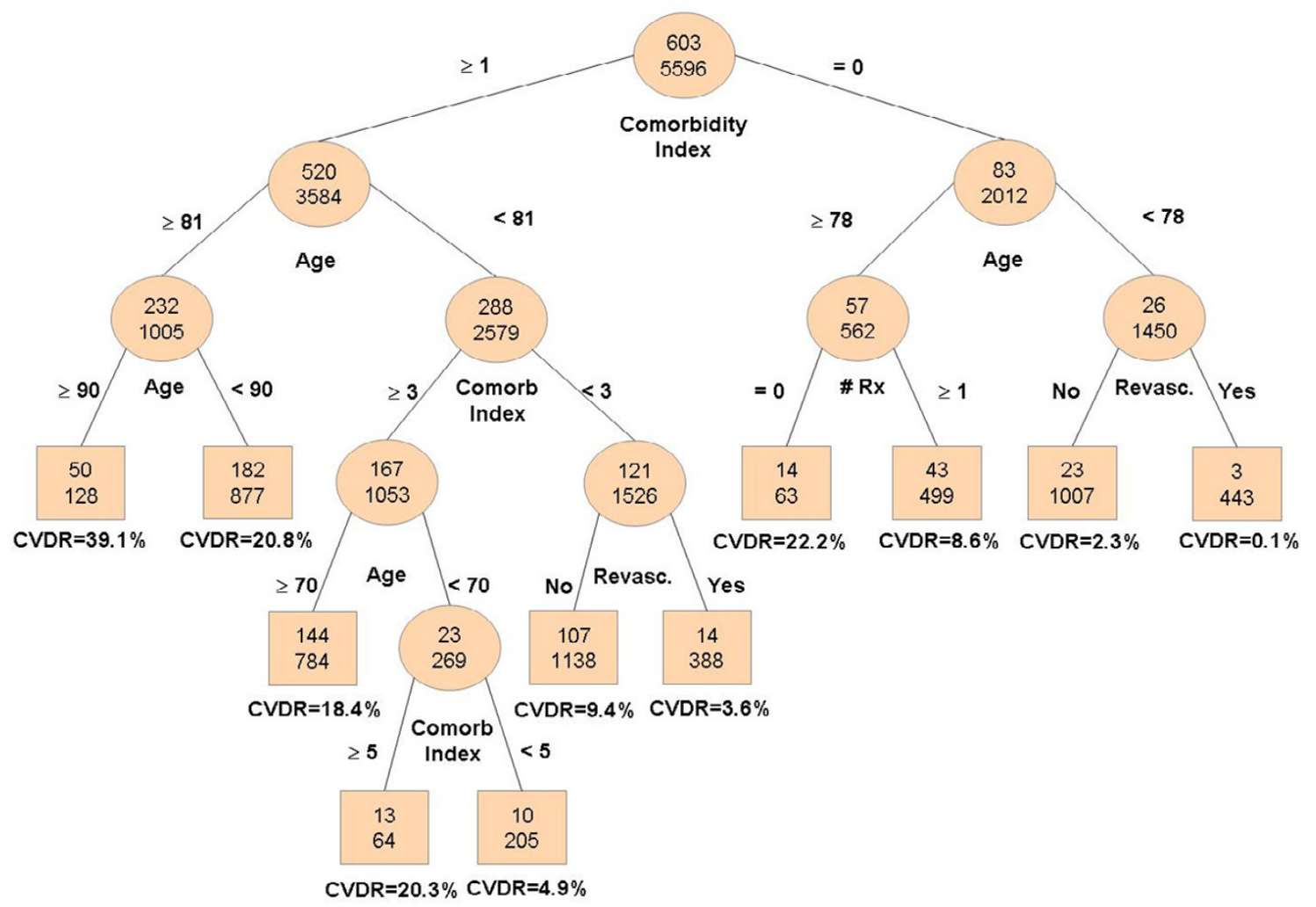

\begin{tabular}{|c|c|c|c|}
\hline \multicolumn{4}{|c|}{ MULTIPLE LOGISTIC REGRESSION } \\
\hline & OR & $95 \% \mathrm{Cl}$ & Wald $\chi^{2}$ \\
\hline Age & 1.073 & $1.059 ; 1.087$ & 116 \\
\hline Male gender & 1.004 & $0.837 ; 1.204$ & 0.0 \\
\hline Comorbidity index & 1.286 & $1.231 ; 1.344$ & 127 \\
\hline Revascularization & 0.368 & $0.259 ; 0.524$ & 31 \\
\hline $\begin{array}{l}\text { Number of classes } \\
\text { of medication }\end{array}$ & & & 16 \\
\hline 1 vs 0 & 0.942 & $0.719 ; 1.235$ & \\
\hline 2 vs 0 & 0.755 & $0.584 ; 0.975$ & \\
\hline 3 vs 0 & 0.696 & $0.518 ; 0.936$ & \\
\hline 4 vs 0 & 0.406 & $0.226 ; 0.729$ & \\
\hline
\end{tabular}

\section{Figure 4}

Predictors of 2-year cardiovascular (CV) death: Regression tree* and logistic regression approaches $(\mathrm{n}=5596)$. * The top number in the nodes represents the number of CV deaths and the number below is the total number of individuals in the specific class. CVDR: Cardiovascular death rate.

time with mortality in patients undergoing angioplasty for acute myocardial infarction. JAMA 2000, 283(22):294I-7.

3. Goldberg RJ, Mooradd M, Gurwitz JH, Rogers WJ, French WJ, Barron HV, Gore JM: Impact of time to treatment with tissue plasminogen activator on morbidity and mortality following acute myocardial infarction (The second National Registry of Myocardial Infarction). Am J Cardiol I 998, 82(3):259-64.
4. Gunnar RM, Passamani ER, Bourdillon PD, Pitt B, Dixon DW, Rapaport E, Fuster V, Reeves T], Karp RB, Russell RO Jr, Guidelines for the early management of patients with acute myocardial infarction, et al:: A report of the American College of Cardiology/American Heart Association Task Force on Assessment of Diagnostic and Therapeutic Cardiovascular Procedures. J Am Coll Cardiol 1990, 16:249-292. 
5. Mehta RH, Montoye CK, Gallogly M, Baker P, Blount A, Faul J, Roychoudhury C, Borzak S, Fox S, Franklin M, Freundl M, Kline-Rogers E, LaLonde T, Orza M, Parrish R, Satwicz M, Smith MJ, Sobotka P, Winston S, Riba AA, Eagle KA, for the GAP Steering Committee of the American College of Cardiology: Improving quality of care for acute myocardial infarction: the guidelines applied in practice (GAP) initiative. JAMA 2002, 287( I 0): 1269-76.

6. Ryan TJ, Antman EM, Brooks NH, Califf RM, Hillis LD, Hiratzka LF, Rapaport E, Riegel B, Russell RO, Smith EE 3rd, Weaver WD, Gibbons RJ, Alpert JS, Eagle KA, Gardner TJ, Garson A Jr, Gregoratos G, Ryan TJ, Smith SC Jr: 1999 update: ACC/AHA guidelines for the management of patients with acute myocardial infarction. A report of the ACC/AHA Task Force on practice guidelines. J Am Coll Cardiol I999, 34(3):890-9| I.

7. Whisenant BK, Wolfe CL: Acute myocardial infarction. Recommendations for medical management and primary angioplasty. Postgrad Med 1997, 102(3): I59-72.

8. Antoniucci D, Valenti R, Migliorini A, Moschi G, Trapani M, Buonamici P, Cerisano G, Bolognese L, Santoro GM: Relation of time to treatment and mortality in patients with acute myocardial infarction undergoing primary coronary angioplasty. American Journal of Cardiology 2002, 89( I I): I248- I252.

9. Chodek A, Angioi M, Fajraoui M, Moulin F, Chouihed T, Maurer P, Mejean C, Carteaux JP, Popovic B, Piquemal R, Ethevenot G, Aliot E: Facteurs pronostiques de mortalite chez les patients en état de choc cardiogenique primaire traites par angioplastie en phase aigue d'infarctus. Annales de Cardiologie et $d$ Angeiologie 2005, 54(2):74-79.

10. De Luca G, Suryapranata H, Ottervanger JP, Antman EM: Time delay to treatment and mortality in primary angioplasty for acute myocardial infarction: every minute of delay counts. [see comment]. Circulation 2004, I09( I 0): I 223-1225.

II. Velianou JL, Wilson SH, Reeder GS, Caplice NM, Grill DE, Holmes DR Jr, Bell MR: Decreasing mortality with primary percutaneous coronary intervention in patients with acute myocardial infarction: the Mayo Clinic experience from 1991 through 1997. [see comment]. Mayo Clinic Proceedings 2000, 75(10):994-100I.

12. Steffenino G, Santoro GM, Maras P, Mauri F, Ardissino D, Violini R, Chiarella F, Lucci D, Marini M, Baldasseroni S, Maggioni AP: In-hospital and one-year outcomes of patients with high-risk acute myocardial infarction treated with thrombolysis or primary coronary angioplasty. Ital Heart J 2004, 5(2): 136-45.

13. Arós F, Marrugat J, López-Bescos L, Cabadés A, Loma-Osorio A, Bosch X, the PRIAMHO Investigators: Accessibility to coronary angiography and one-year survival after myocardial infarction. Am J Cardiol 2002, 90(4):409-I2.

14. Alter DA, Naylor CD, Austin PC, Tu JV: Long-term MI outcomes at hospitals with or without on-site revascularization. JAMA 200I, 285(16):210I-2108.

15. Yusuf S, Wittes J, Friedman L: Overview of results of randomised clinical trials in heart disease. I. Treaments following myocardial infarction. JAMA 1988, 260(14):2088-2093.

16. Garg R, Yusuf S: Overwiew of randomised trials of angiotensinconverting enzyme inhibitors on mortality and morbidity in patients with heart failure. Collaborative Group on ACE inhibitors trials. JAMA 1995, 273:|450-| 456.

17. Scandinavian Simvastatin Survival Study Group: Randomised trial of cholesterol lowering in 4,444 patients with coronary heart disease: The Scandinavian Simvastatin Survival Study (4S). Lancet 1994, 344: 1383-1389.

18. Sacks FM, Pfeffer MA, Moye LA, Rouleau JL, Rutherford J, Cole TG, Brown L, Warnica JW, Arnold JM, Wun CC, Davis BR, Braunwald E: The effect of pravastatin on coronary events after myocardial infarction in patients with average cholesterol levels. $\mathrm{N}$ Engl J Med 1996, 335:1001-1009.

19. Allen Maycock CA, Muhlestein JB, Horne BD, Carlquist JF, Bair TL, Pearson RR, Li Q, Anderson JL, Intermountain Heart Collaborative S: Statin therapy is associated with reduced mortality across all age groups of individuals with significant coronary disease, including very elderly patients. Journal of the American College of Cardiology 2002, 40( I 0): 1777-I785.

20. Aronow HD, Topol EJ, Roe MT, Houghtaling PL, Wolski KE, Lincoff AM, Harrington RA, Califf RM, Ohman EM, Kleiman N, Keltai M, Wilcox RG, Vahanian A, Armstrong PW, Lauer MS: Effect of lipid-lowering therapy on early mortality after acute coronary syndromes: an observational study. [see comment]. Lancet 200I, 357(9262): 1063-1068.

21. Bickel C, Rupprecht HJ, Blankenberg S, Espiniola-Klein C, Schlitt A, Rippin G, Hafner G, Treude R, Othman H, Hofmann KP, Meyer J, AtheroGene Investigators: Relation of markers of inflammation (C-reactive protein, fibrinogen, von Willebrand factor, and leukocyte count) and statin therapy to long-term mortality in patients with angiographically proven coronary artery disease. American Journal of Cardiology 2002, 89(8):901-908.

22. Bunch TJ, Muhlestein JB, Bair TL, Renlund DG, Lappe DL, Jensen KR, Horne BD, Carter MA, Anderson JL, Intermountain Heart Collaborative Study G: Effect of beta-blocker therapy on mortality rates and future myocardial infarction rates in patients with coronary artery disease but no history of myocardial infarction or congestive heart failure. American Journal of Cardiology 2005, 95(7):827-83।.

23. Chan AW, Quinn MJ, Bhatt DL, Chew DP, Moliterno DJ, Topol EJ, Ellis SG: Mortality benefit of beta-blockade after successful elective percutaneous coronary intervention. Journal of the American College of Cardiology 2002, 40(4):669-675.

24. Coletta C, Ricci R, Ceci V, Seccareccia F, Rulli F, Mazzuca V, Putini RL, Salustri A, Bottero G, Pasquale M: Effects of early treatment with captopril and metoprolol singly or together on six-month mortality and morbidity after acute myocardial infarction. Results of the RIMA (Rimodellamento Infarto Miocardico Acuto) study. The RIMA researchers. [see comment]. Giornale Italiano di Cardiologia 1999, 29(2): I I5- I24. discussion I25-I I9

25. Ellis K, Tcheng JE, Sapp S, Topol EJ, Lincoff AM: Mortality benefit of beta blockade in patients with acute coronary syndromes undergoing coronary intervention: pooled results from the Epic, Epilog, Epistent, Capture and Rapport Trials. Journal of Interventional Cardiology 2003, I 6(4):299-305.

26. Hague W, Forder P, Simes J, Hunt D, Tonkin A, LIPID Investigators: Effect of pravastatin on cardiovascular events and mortality in 1516 women with coronary heart disease: results from the Long-Term Intervention with Pravastatin in Ischemic Disease (LIPID) study. American Heart Journal 2003, I45(4):643-65I.

27. Horne BD, Muhlestein JB, Carlquist JF, Bair TL, Madsen TE, Hart NI, Anderson JL: Statin therapy, lipid levels, C-reactive protein and the survival of patients with angiographically severe coronary artery disease. [see comment]. Journal of the American College of Cardiology 2000, 36(6): 1774- 1780.

28. Liu L, Chinese Cardiac Study Collaborative G: Long-term mortality in patients with myocardial infarction: impact of early treatment with captopril for $\mathbf{4}$ weeks. Chinese Medical Journal 200I, II 4(2): II5-II8

29. Otterstad JE, Ford I: The effect of carvedilol in patients with impaired left ventricular systolic function following an acute myocardial infarction. How do the treatment effects on total mortality and recurrent myocardial infarction in CAPRICORN compare with previous beta-blocker trials? European Journal of Heart Failure 2002, 4(4):50I-506.

30. Stenestrand U, Wallentin L, Swedish Register of Cardiac Intensive C: Early statin treatment following acute myocardial infarction and I-year survival. JAMA 200I, 285(4):430-436.

31. Fonarow GC, Wright RS, Spencer FA, Fredrick PD, Dong W, Every N, French W], National Registry of Myocardial Infarction 4 Investigators: Effect of statin use within the first $\mathbf{2 4}$ hours of admission for acute myocardial infarction on early morbidity and mortality. Am J Cardiol 2005, 96(5):6II-6.

32. Psaty BM, Anderson M, Kronmal RA, Tracy RP, Orchard T, Fried LP, Lumley T, Robbins J, Burke G, Newman AB, Furberg CD: The association between lipid levels and the risks of incident myocardial infarction, stroke, and total mortality: The Cardiovascular Health Study. J Am Geriatr Soc 2004, 52(10): 1639-47.

33. Aronow WS, Ahn C, Kronzon I: Effect of propranolol versus no propranolol on total mortality plus nonfatal myocardial infarction in older patients with prior myocardial infarction, congestive heart failure, and left ventricular ejection fraction $>$ or $=\mathbf{4 0} \%$ treated with diuretics plus angiotensin-converting enzyme inhibitors. Am J Cardiol 1997, 80(2):207-9.

34. Cleland JG, Erhardt L, Murray G, Hall AS, Ball SG: Effect of ramipril on morbidity and mode of death among survivors of acute myocardial infarction with clinical evidence of heart failure. 
A report from the AIRE Study Investigators. Eur Heart ] 1997, I8(I):4I-5I.

35. Matts JP, Buchwald H, Fitch LL, Campos CT, Varco RL, Campbell GS, Pearce MB, Yellin AE, Smink RD Jr, Sawin HS Jr, Long JM, for The Posch Group: Subgroup analyses of the major clinical endpoints in the Program on the Surgical Control of the Hyperlipidemias (POSCH): overall mortality, atherosclerotic coronary heart disease (ACHD) mortality, and ACHD mortality or myocardial infarction. I Clin Epidemiol 1995 48(3):389-405.

36. Heart Protection Study Collaborative Group: MRC/BHF Heart Protection Study of cholesterol lowering with simvastatin in 20,536 high-risk individuals: a randomised placebo-controlled trial. Lancet 2002, 360(9326):7-22.

37. Herlitz J, Dellborg M, Karlson BW, Lindqvist J, Karlsson T, Sanden W, Sjolin $M$, Wedel $\mathrm{H}$ : Changes in the use of medications after acute myocardial infarction: possible impact on mortality after myocardial infarction and long-term outcome. Coronary Artery Disease 200I, I 2(I):6I-67.

38. Hognestad A, Dickstein K, Myhre E, Snapinn S, Kjekshus J, OPTIMAAL Investigators: Effect of combined statin and beta-blocker treatment on one-year morbidity and mortality after acute myocardial infarction associated with heart failure. American Journal of Cardiology 2004, 93(5):603-606.

39. Krause MW, Massing M, Kshirsagar A, Rosamond W, Simpson RJ Jr: Combination therapy improves survival after acute myocardial infarction in the elderly with chronic kidney disease. Renal Failure 2004, 26(6):715-725

40. Mukherjee D, Fang J, Chetcuti S, Moscucci M, Kline-Rogers E, Eagle KA: Impact of combination evidence-based medical therapy on mortality in patients with acute coronary syndromes. Circulation 2004, 109:745-9.

4I. Levy AR, Tamblyn RM, Fitchett D, McLeod PJ, Hanley JA: Coding accuracy of hospital discharge data for elderly survivors of myocardial infarction. Can J Cardiol I999, I5(I I): 1277-82.

42. Petersen LA, Wright S, Normand SL, Daley J: Positive predictive value of the diagnosis of acute myocardial infarction in an administrative database. J Gen Intern Med 1999, 14:555-8.

43. D'Hoore W, Bouckaert A, Tilquin C: Practical considerations on the use of the Charlson Comorbidity index with administrative data bases. J Clin Epidemiology 1996, 49( I 2): 1429-33.

44. Hosmer DW, Lemeshow S: Applied Logistic Regression New York: Wiley \& Sons; 1989.

45. Zhang HP, Bracken M: Tree-based risk factor analysis of preterm delivery and small-for-gestational-age birth. Am J Epidemiol 1995, 141:70-8.

46. Zhang HP, Holford T, Bracken M: A tree-based method in prospective studies. Stat Med 1996, 15:37-50.

47. Nicolucci $A$, Carinci $F$, Ciampi $A$ : Stratifying patients at risk of diabetic complications: An integrated look at clinical, socioeconomic and care-related factors. Diabetes Care 1998, 2I(9): I 439-44.

48. Breiman L, Friedman JH, Olshen RA, Stone C: Classification and Regression Trees Belmont, CA: Wadsworth International Group; 1984.

49. Ciampi A, Hogg S, McKinney S, Thiffault J: RECPAM: a computer program for recursive partition and amalgamation for censored survival data and other situations frequently occurring in biostatistics. I. Methods and program features. Comput Methods Programs Biomed 1988, 26:239-56.

50. de Gevigney G, Ecochard R, Colin C, Rabilloud M, Excoffier S, Cao D, Cheneau E, Milon H, Delahaye F, PRIMA group: Characteristics, management, and inhospital mortality of acute myocardial infarction in the "real world" in France - data from a large unselected cohort of 2,519 consecutive patients in a French region. Acta Cardiol 2000, 55(6):357-66.

51. Dauerman HL, Yarzebski J, Gore JM, Lessard D, Goldberg RJ: Use of the invasive management strategy for patients with non-Qwave myocardial infarction: an observational database report from the Worcester Heart Attack Study. Am Heart J 2002, I 43(6): I033-9.

52. Amit G, Goldman S, Ore L, Low M, Kark JD: The association between hospital department, medical treatment and outcome in acute myocardial infarction. Isr Med Assoc J 2003, 5(4):255-9.
53. Scott IA, Coory MD, Harper CM: The effects of quality improvement interventions on inhospital mortality after acute myocardial infarction. Med J Aust 200I, I 75(9):465-70.

54. Sheikh K, Bullock C: Urban-rural differences of care for medicare patients with acute myocardial infarction. Arch Intern Med 200I, I6I(5):737-53.

55. Vu HD, Heller RF, Lim LLY, D'este C, O'Connell RL: Mortality after acute myocardial infarction is lower in metropolitan regions than in non-metropolitan regions. J Epidemiol Community Health 2000, 54:590-5.

56. Lim LLY, O'Connell RL, Heller RF: Differences in management of heart attack patients between metropolitan and regional hospitals in the Hunter Region of Australia. Aust New Zeal J Pub Health 1999, 23(I):6I-6.

\section{Pre-publication history}

The pre-publication history for this paper can be accessed here:

http://www.biomedcentral.com/1471-2261/6/21/prepub
Publish with Biomed Central and every scientist can read your work free of charge

"BioMed Central will be the most significant development for disseminating the results of biomedical research in our lifetime. "

Sir Paul Nurse, Cancer Research UK

Your research papers will be:

- available free of charge to the entire biomedical community

- peer reviewed and published immediately upon acceptance

- cited in PubMed and archived on PubMed Central

- yours - you keep the copyright 